\title{
Alien introgressions and chromosomal rearrangements do not affect the activity of gliadin-coding genes in hybrid lines of Triticum aestivum L. $\times$ Aegilops columnaris Zhuk.
}

\author{
A.Yu. Novoselskaya-Dragovich @, A.A. Yankovskaya, E.D. Badaeva
}

Vavilov Institute of General Genetics, RAS, Moscow, Russia

Using chromosome C-banding and electrophoresis of grain storage proteins, gliadins, 17 Triticum aestivumAegilops columnaris lines with substitutions of chromosomes of homoeologous groups 1 and 6 were examined. Based on their high polymorphism, gliadins were used to identify alien genetic material. For all of the lines examined, electrophoretic analysis of gliadin spectra confirmed substitution of wheat chromosomes 6A, 6D or 1D for the homoeologous Aegilops chromosomes of genomes $U^{c}$ or $X^{c}$. The substitution manifested in the disappearance of the products of gliadin-coding genes on chromosomes $6 \mathrm{~A}, 6 \mathrm{D}$ or $1 \mathrm{D}$ with the simultaneous appearance of the products of genes localized on alien chromosomes of genomes Uc or Xc. Thus, Aegilops chromosomes were shown to be functionally active in the alien wheat genome. The absence of alien genes expression in the lines carrying a long arm deletion in chromosome $6 \mathrm{X}^{\mathrm{C}}$ suggested that the gliadin-coding locus moved from the short chromosome arm (its characteristic position in all known wheat species) to the long one. This is probably associated with a large speciesspecific pericentric inversion. In spite of losing a part of its long arm and combination with a non-homologous chromosome of a different genome (4BL), chromosome 1D was fully functioning. For Aegilops, the block type of gliadin components inheritance was shown, indicating similarity in the structural organization of gliadin-coding loci in these genera. Based on determining genetic control of various polypeptides in the electrophoretic aegilops spectrum, markers to identify Ae. columnaris chromosomes $1 \mathrm{X}^{\mathrm{c}}, 6 \mathrm{X}^{\mathrm{c}}$ and $6 \mathrm{U}^{\mathrm{c}}$ were constructed.

Key words: electrophoresis of gliadin seed storage proteins; gliadins; C-banding; substitution; translocation; Aegilops columnaris; wheat; introgression.

\section{Интрогрессии и хромосомные перестройки не влияют на активность глиадинкодирующих генов в линиях гибридов Triticum aestivum L. $\times$ Aegilops columnaris Zhuk.}

\author{
А.Ю. Новосельская-Арагович $\otimes$, А.А. Янковская, \\ Е.А. Бадаева
}

Институт общей генетики им. Н.И. Вавилова Российской академии наук Москва, Россия

Вид дикорастущей пшеницы Aegilops columnaris Zhuk. представляет собой потенциальный источник новых генов, важных для улучшения хозяйственно ценных признаков пшеницы. До настоящего времени он не использовался в селекционных программах. В работе методами С-окрашивания хромосом и электрофореза запасных белков зерна мягкой пшеницы - глиадинов - проанализированы 17 линий Triticum aestivum L. $\times$ Aegilops columnaris Zhuk. с замещениями по хромосомам 1-й и 6-й гомеологических групп. Глиадин за счет высокого полиморфизма позволил идентифицировать чужеродный генетический материал. Для всех исследованных линий анализ электрофоретических спектров глиадина подтвердил замещение хромосом 6A, 6D или 1D мягкой пшеницы на гомеологические хромосомы эгилопса Ae. columnaris Zhuk., относящиеся к Uс или X'-геномам. Замещение проявлялось в исчезновении продуктов экспрессии глиадинкодирующих генов на хромосомах 6A, 6D или 1D с одновременным появлением продуктов экспрессии генов, локализованных на чужеродных для пшеницы хромосомах U` или X'-геномов. Таким образом, показана функциональная активность эгилопсных хромосом в чужеродном для них пшеничном геноме. Отсутствие экспрессии чужеродных глиадинкодирующих генов у линий с делецией длинного плеча хромосомы 6Хс позволило выдвинуть гипотезу о перемещении глиадинкодирующего локуса из короткого плеча (что характерно для всех известных видов пшеницы) в длинное. Перемещение глиадинкодирующего локуса, вероятно, связано с крупной видоспецифической перицентрической инверсией цитогенетический анализ показал существенные различия ортологичных хромосом 6-й группы Х-генома по морфологии. B то же время хромосома 1D, независимо от потери части длинного плеча и объединения с негомологичной хромосомой другого генома (4BL), полноценно функционирует. Для эгилопса показан «блочный» характер наследования компонентов глиадина, что свидетельствует о сходстве 
организационной структуры глиадинкодирующих локусов у представителей этих родов. Определение генетического контроля разных полипептидов электрофоретического спектра эгилопса позволило разработать маркеры для идентификации хромосом $1 \mathrm{X}^{\mathrm{c}}, 6 \mathrm{X}^{\mathrm{c}}$ и $6 \mathrm{U}^{\mathrm{c}}$ Ae. columnaris.

Ключевые слова: электрофорез запасных белков; глиадины; дифференциальное окрашивание; замещения; транслокации; Aegilops columnaris; пшеница; интрогрессия.

\begin{abstract}
HOW TO CITE THIS ARTICLE:
\end{abstract}
Novoselskaya-Dragovich A.Yu.,Yankovskaya A.A., Badaeva E.D. Alien introgressions and chromosomal rearrangements do not affect the activity of gliadin-coding genes in hybrid lines of Triticum aestivum L. ×Aegilops columnaris Zhuk. Vavilovskii Zhurnal Genetiki i Selektsii = Vavilov Journal of Genetics and Breeding. 2018;22(5):507-514. DOI 10.18699/VJ18.388

$\mathrm{T}$ o improve common wheat, allied wild species, particularly those representing Aegilops L. genus, are used as donors of agriculturally valuable traits. A significant number of genes, especially the ones responsible for resistance to diseases, pests, drought, and other stress factors, were introduced into the common wheat genome from various species of this genus (Damania et al., 1992; Friebe et al., 1996; Monneveux et al., 2000; Schneider et al., 2008; McIntosh et al., 2013; Molnár-Láng et al., 2014, 2015). Moreover, various Aegilops species are used to improve grain quality of wheat cultivars (Garg et al., 2008, 2016; Tiwari et al., 2010; Rawat et al., 2011; Rakszegi et al., 2017).

In recent decades a full or nearly full spectrum of TriticumAegilops addition or substitution lines has been derived for more than ten Aegilops species (see surveys in Schneider et al., 2008; Molnár-Láng et al., 2015). However, it was not until recently that lines of wheat with introgression from Ae. columnaris Zhuk. have been successfully developed. Aegilops columnaris is a tetraploid species with $\mathrm{U}^{c} \mathrm{X}^{\mathrm{c}}$ genomic formula (Dvořák, 1998; Badaeva et al., 2004), which possesses a number of valuable breeding traits, particularly drought tolerance and resistance to diseases and pests (Gill et al., 1985; Warham et al., 1986; Damania et al., 1992). A set of T. aestivum $\times$ Ae. columnaris lines has been derived by researchers at Genetics and Cytology Laboratory at Agricultural Research Institute for South-East Region (Saratov, Russia). Earlier, analysis of 84 lines using differential chromosome banding showed that hybrids differ in introgression spectra (Shishkina et al., 2017; Badaeva et al., 2018). The material studied included lines with additions and/or substitutions of chromosomes of homoeologous groups 1 and 6 .

It was shown that genes coding grain storage proteins, gliadins, in grasses are localized in short arms of chromosomes of homoeologous groups 1 and 6 (Shepherd, 1968; Kasarda et al., 1976; Singh, Shepherd, 1988). Gliadins visualized by PAGE electrophoresis are highly polymorphic proteins controlled by multiple alleles of six non-linked gliadin-coding (GC) loci (Gli-A1, Gli-B1, Gli-D1, Gli-A2, Gli-B2, Gli-D2). As each $\mathrm{GC}$ locus is a cluster of tightly linked genes, the polypeptides controlled by these clusters appear on electrophoregrams as blocks of components inherited as a single Mendelian character. Multiple allelism in GC loci permits not only reliable identification of wheat cultivars, but also determination of their internal structure, i. e. biotype/haplotype composition. Thus, EP analysis of grain storage proteins is widely used in genetic research of wheat for cultivar certification purposes, identification of population structure, biodiversity investigation, gene mapping, and solving many other problems.
Gliadin genetics is studied quite thoroughly, and GC loci alleles are identified for many domestic and foreign cultivars (see the survey in Novoselskaya-Dragovich, 2015). However, genetic control of gliadins in Aegilops species, and Ae. columnaris in particular, is scarcely studied. Analysis of Triticum-Ae. columnaris lines with chromosome introgression of groups 1 and 6 permits not only to identify GC locus alleles controlled by Aegilops chromosomes, but also to develop identification markers for Ae. columnaris genetic material and evaluate effects of Aegilops chromosome introgression on gene expression in wheat.

Thus, the objective of our study was clarify the genome structure in introgressive lines and analyze alien gene expression in wheat genome by EP analysis of storage proteins.

\section{Materials and methods}

In the present study, 17 Triticum-Ae. columnaris introgressive lines with chromosome substitution in homoeologous groups 1 and 6 were examined (see the Table). The Dobrynya and L-503 wheat cultivars $(2 n=42)$ with T7DL-7Ai Triticum-Agropyrim translocation, as well as the Saratovskaya 68 cultivar with a standard set of wheat chromosomes, were taken as female parents (Badaeva et al., 2018). K-1193 Ae. columnaris line $(2 n=28)$ acted as a male parent.

Gliadin extraction and electrophoresis in polyacrylamide gel were performed using standard techniques (Upelniek et al., 2013). GC locus alleles were classified according to the catalog (Metakovsky, Novoselskaya, 1991).

Differential chromosome banding (C-banding) was performed as in Badaeva et al., 1994. Wheat chromosomes were classified based on the genetic nomenclature (Gill et al., 1991); to classify Ae. columnaris chromosomes, the nomenclature developed at our laboratory was used (Badaeva et al., 2018).

\section{Results}

Using gliadin EP spectra analysis, we identified GC locus alleles in all common wheat introgressive lines and parental cultivars (see the Table). The hybrids were shown to inherite alleles only from one of two previously established haplotypes of Dobrynya and L-503 cultivars (Novoselskaya-Dragovich et al., 2003) (see the Table). EP spectra of the lines match those of the parental cultivars. For instance, line1794/1 inherited Gli-A1m and Gli-B2d from the Saratovskaya 68 cultivar and Gli-B1e, Gli-D1a, Gli-A2s - from Dobrynya. Gli-Alf allele uncharacteristic for the parental wheat cultivar was found only in line 2304/1. Probably, it was introduced as a result of random cross-pollination. All the Ae. columnaris 
Cytogenetic and genetic characteristics of T. aestivum - Ae. columanris introgressive lines

\begin{tabular}{|c|c|c|c|c|c|c|c|c|c|c|c|}
\hline \multirow[t]{2}{*}{ № } & \multirow[t]{2}{*}{ Cultivar/Line } & \multirow[t]{2}{*}{$2 n$} & \multirow{2}{*}{$\begin{array}{l}\text { Cytological characteristics } \\
\text { of lines }\end{array}$} & \multirow{2}{*}{$\begin{array}{l}\text { Genetic } \\
\text { characteristics } \\
\text { of lines }\end{array}$} & \multicolumn{6}{|c|}{ Gliadin-coding locus alleles Gli- } & \multirow{2}{*}{$\begin{array}{l}\text { Biotypes/ } \\
\text { Chromosome } \\
\text { substitutions }\end{array}$} \\
\hline & & & & & $A 1$ & B1 & $D 1$ & $A 2$ & $B 2$ & $D 2$ & \\
\hline \multirow[t]{2}{*}{1} & Dobrynya & 42 & T7DL-7Ai & Cultivar consists & $i$ & $e$ & $a$ & s & $q$ & $e$ & Biotype 1 \\
\hline & & & & $\begin{array}{l}\text { Of two blotypes, } \\
\text { Gli-B2q/Gli-B2s }\end{array}$ & $i$ & $e$ & $a$ & $s$ & $s$ & $e$ & Biotype 2 \\
\hline \multirow[t]{2}{*}{2} & $\mathrm{~L}-503$ & 42 & T7DL-7Ai & Cultivar consists & $i$ & $e$ & $a$ & $q$ & $q x$ & $e$ & Biotype 1 \\
\hline & & & & $\begin{array}{l}\text { of two biotype, } \\
\text { Gli-A1i/Gli-A1m }\end{array}$ & $m$ & $e$ & $a$ & $q$ & $q x$ & $e$ & Biotype 2 \\
\hline 3 & Saratovskaya 68 & 42 & - & $\begin{array}{l}\text { Monomorphic } \\
\text { cultivar }\end{array}$ & $m$ & $e$ & $f$ & 0 & $d$ & $e$ & \\
\hline 4 & $1721 / 1$ & 40 & $\begin{array}{l}\text { Disomic substitution of } 6 \mathrm{~A}(6 \mathrm{Uc}) \text {. } \\
\text { Terminal deletion of 1BL. 6A } \\
\text { and 1D absent; disomic T4BL-1D } \\
\text { and T7DL-7Ai }\end{array}$ & $\begin{array}{l}\text { 1D functional; } \\
6 \mathrm{~A} \text { absent, } \\
6 \mathrm{U}^{\mathrm{C}} \text { expressed }\end{array}$ & $i$ & $e$ & $a$ & $6 U^{c}$ & $s$ & $e$ & $6 A\left(6 U^{c}\right)$ \\
\hline 5 & $1776 / 1$ & 40 & id. & id. & $i$ & $e$ & $a$ & $6 U^{c}$ & $s$ & $e$ & $6 A\left(6 U^{c}\right)$ \\
\hline 6 & $1777 / 4$ & 40 & $»$ & $»$ & $i$ & $e$ & $a$ & $6 U^{c}$ & $s$ & $e$ & $6 A\left(6 U^{c}\right)$ \\
\hline 7 & $2307 / 1 \mathrm{~W}$ & 40 & $»$ & $»$ & $i$ & $e$ & $a$ & $6 U^{c}$ & $s$ & $e$ & $6 A\left(6 U^{c}\right)$ \\
\hline 8 & $2307 / 1 w$ & 43 & $\begin{array}{l}\text { Disomic addition of } 6 \mathrm{U}^{\mathrm{c}} \\
4 \mathrm{~B}+1 \mathrm{D} / \mathrm{T} 4 \mathrm{BL}-1 \mathrm{D} \text { or } 4 \mathrm{~B}(\mathrm{~T} 4 \mathrm{~B}-1 \mathrm{D}) \text {. } \\
\text { T7DL-7Ai }\end{array}$ & $»$ & $i$ & $e$ & $a$ & $s+6 U^{c}$ & $s$ & $e$ & $6 A+6 U^{c}$ \\
\hline 9 & $2308 / 5$ & 40 & $»$ & $\begin{array}{l}\text { 1D functional; } \\
6 \mathrm{~A} \text { absent, } 6 \mathrm{U}^{\mathrm{C}} \mathrm{ex}- \\
\text { pressed (in one dose) }\end{array}$ & $i$ & $e$ & $a$ & $6 U^{c}$ & $s$ & $e$ & $6 A\left(6 U^{c}\right)$ \\
\hline 10 & $1777 / 1$ & 42 & $\begin{array}{l}\text { Double disomic substitution } \\
\text { of } 5 D\left(5 X^{c}\right) 6 A\left(6 X^{c}\right) \text {. Terminal dele- } \\
\text { tion of } 1 B L ; \text { splitting by chromo- } \\
\text { somes } 7 B \text { and } 7 D / T 7 D L-7 A\end{array}$ & $\begin{array}{l}6 \mathrm{~A} \text { absent, } \\
6 \mathrm{U}^{\mathrm{C}} \text { expressed }\end{array}$ & $m$ & $e$ & $a$ & $s$ & $s$ & $6 X^{c}$ & $6 A\left(6 X^{c}\right)$ \\
\hline 11 & 1813 & 42 & $\begin{array}{l}\text { Disomic substitution of 6D }\left(6 U^{c}\right) \\
\text { T7DL-7Ai }\end{array}$ & $\begin{array}{l}\text { 6D not expressed, } 6 \mathrm{U}^{\mathrm{c}} \\
\text { components appear }\end{array}$ & $i$ & $e$ & $a$ & $q$ & $s$ & $6 U^{c}$ & $6 \mathrm{D}\left(6 \mathrm{U}^{\mathrm{c}}\right)$ \\
\hline 12 & $2054 / 3$ & 42 & id. & $\begin{array}{l}\text { 6D not expressed } 6 \mathrm{U}^{\mathrm{c}} \\
\text { components appear }\end{array}$ & $i$ & $e$ & $a$ & $q$ & $s$ & $6 U^{c}$ & $6 D\left(6 U^{c}\right)$ \\
\hline 13 & $2015 / 2$ & 42 & $\begin{array}{l}\text { Monosomic substitution of 6D/ } \\
6 U^{c} . \text { T7DL-7Ai }\end{array}$ & $\begin{array}{l}\text { 6D not expressed, } 6 \mathrm{U}^{\mathrm{c}} \\
\text { components appear }\end{array}$ & $i$ & $e$ & $a$ & 9 & $q$ & $6 U^{c}$ & $6 D\left(6 U^{c}\right)$ \\
\hline 14 & $2306 / 3$ & 42 & id. & id. & $i$ & $e$ & $a$ & $q$ & $q+s$ & $6 U^{c}$ & $6 \mathrm{D}\left(6 U^{c}\right)$ \\
\hline 15 & $2310 / 1$ & 42 & $\begin{array}{l}\text { Monosomic substitution } \\
\text { of } 6 D / 6 U^{c}, 1 D L \text { with terminal } \\
\text { translocation. T7DL-7Ai }\end{array}$ & $》$ & $i$ & $e$ & $a$ & $q$ & 9 & $6 U^{c}$ & $6 D\left(6 U^{c}\right)$ \\
\hline 16 & $2304 / 1$ & 42 & $\begin{array}{l}\text { Double disomic substitution } \\
\text { of } 5 D\left(5 X^{c}\right) 6 B\left(6 X^{c}\right) \text {. T7DL-7Ai }\end{array}$ & $\begin{array}{l}6 \mathrm{D} \text { not expressed, } \\
6 \mathrm{X}^{\mathrm{C}} \text { expressed }\end{array}$ & $f$ & $e$ & $a$ & 9 & $q$ & $6 X^{c}$ & $6 D\left(6 X^{c}\right)$ \\
\hline 17 & $2033 / 1$ & 40 & $\begin{array}{l}\text { Hybrid; splitting of } 6 \mathrm{D} / 6 \mathrm{Ai}-2+ \\
+5 \mathrm{D} / 5 \mathrm{X}+\text { ?tel } 6 \mathrm{X}^{\mathrm{c}} \mathrm{S}+3 \mathrm{DL} \text { with } \\
\text { terminal translocation, } 6 \mathrm{D} \text { absent }\end{array}$ & id. & $i$ & $e$ & $a$ & $s$ & $s$ & - & - \\
\hline 18 & $2034 / 3-1$ & 42 & $\begin{array}{l}6 \mathrm{D} \text { absent. } 6 X^{c} \text { with large termi- } \\
\text { nal long arm deletion }\end{array}$ & $»$ & $\begin{array}{l}m+i \\
(4: 1)\end{array}$ & $e$ & $a$ & $s$ & $s$ & $6 X^{c}$ & $6 D\left(6 X^{c}\right)$ \\
\hline
\end{tabular}




\section{End of table}

\begin{tabular}{|c|c|c|c|c|c|c|c|c|c|c|c|}
\hline \multirow[t]{2}{*}{ № } & \multirow{2}{*}{$\begin{array}{l}\text { Cultivar/ } \\
\text { Line }\end{array}$} & \multirow[t]{2}{*}{$2 n$} & \multirow{2}{*}{$\begin{array}{l}\text { Cytological characteristics } \\
\text { of lines }\end{array}$} & \multirow{2}{*}{$\begin{array}{l}\text { Genetic } \\
\text { characteristics } \\
\text { of lines }\end{array}$} & \multicolumn{6}{|c|}{ Gliadin-coding locus alleles Gli- } & \multirow{2}{*}{$\begin{array}{l}\text { Biotypes/ } \\
\text { Chromosome } \\
\text { substitutions }\end{array}$} \\
\hline & & & & & $A 1$ & B1 & D1 & $A 2$ & $B 2$ & $D 2$ & \\
\hline 19 & 1930 & 42 & $\begin{array}{l}\text { Disomic substitution of } 1 \mathrm{D}\left(1 \mathrm{Xc}^{\mathrm{C}}\right) \text {. } \\
\text { Nulli-6A, tetra-6D; one } 6 \mathrm{D} \text { pair with } \\
\text { terminal long arm translocation. } \\
\text { T7DL-7Ai }\end{array}$ & $\begin{array}{l}1 \mathrm{D} \text { and } 6 \mathrm{~A} \\
\text { not expressed, } 1 \mathrm{X}^{\mathrm{c}} \\
\text { expressed, tetra-6D }\end{array}$ & $i$ & $e$ & $1 X^{c}$ & - & $q$ & $e$ & $1 \mathrm{D}\left(1 \mathrm{X}^{\mathrm{c}}\right)$ \\
\hline 20 & $1794 / 1$ & 42 & $\begin{array}{l}\text { 6D substituted T7U'S:6X's; } \\
\text { T7DL-7Ai }\end{array}$ & $\begin{array}{l}6 \mathrm{D} \text { and } 6 \mathrm{X}^{\mathrm{c}} \\
\text { not expressed }\end{array}$ & $m$ & $e$ & $a$ & $s$ & $s$ & - & - \\
\hline
\end{tabular}

Notes: $2 n$-chromosomes number, Gliadin-coding loci Gli-A1, Gli-B1, Gli-D1, Gli-A2, Gli-B2, Gli-D2 controlled by chromosomes 1A, 1B, 1D, 6A, 6B и 6D, respectively.

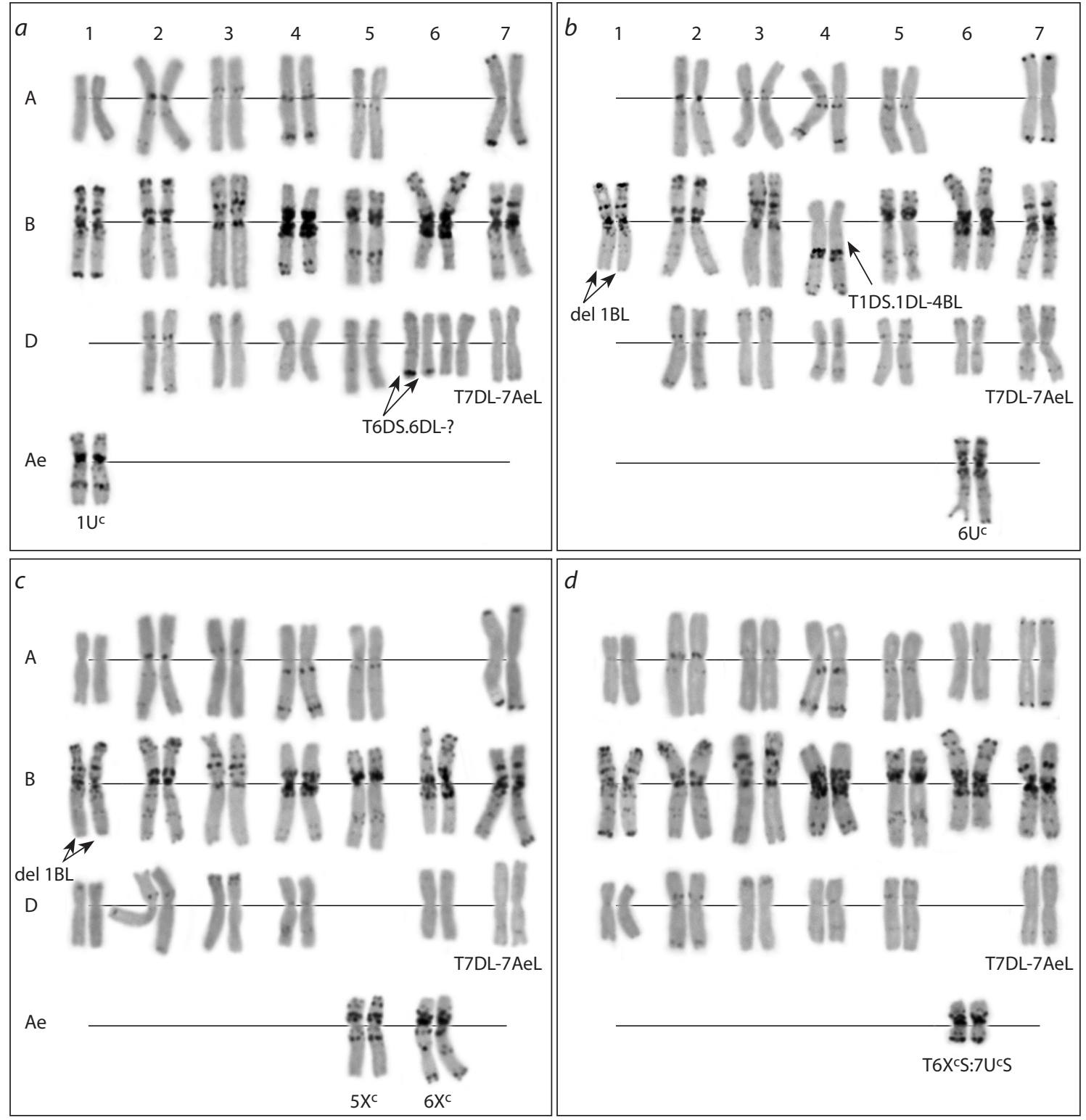

Fig. 1. Karyotypes of introgressive lines T. aestivum $\times$ Ae. columnaris, K-1193. $a-1930 ; b-2308 ; c-1771 / 1 ; d-1794 / 1$.

A, B, D - Common wheat genomes, Ae - genome of Ae. columnaris, 1-7 - homoeologous groups. Numbers of alien chromosomes are shown at the bottom of the figure. Chromosomes rearrangements are indicated with arrows. 
$a$

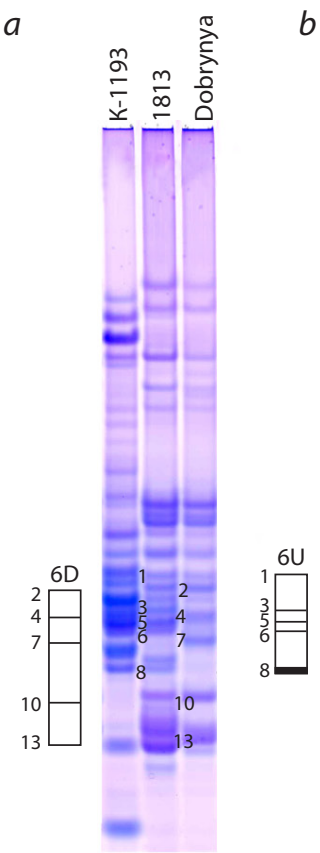

e

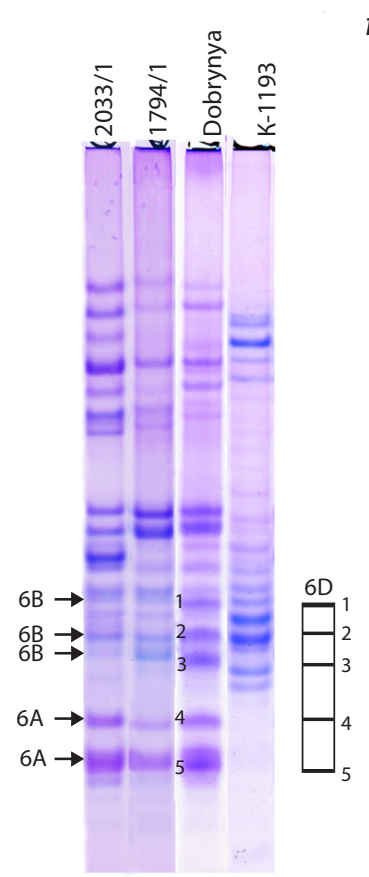

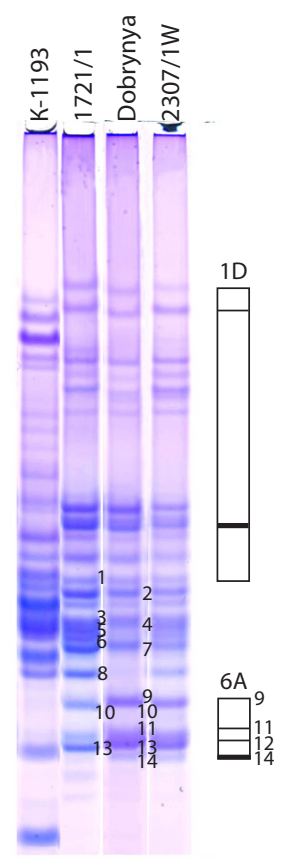

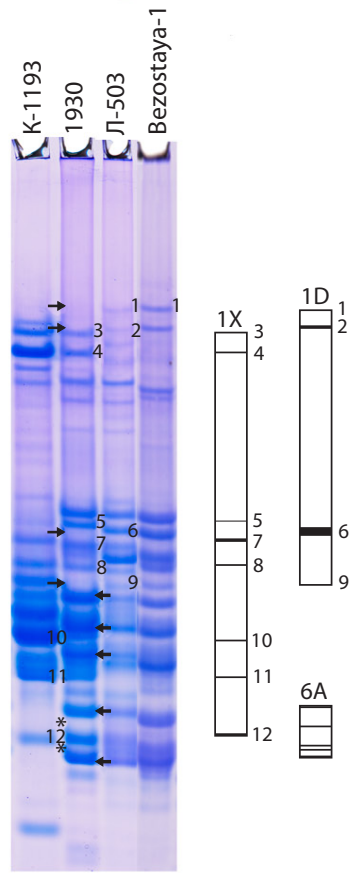

$c$

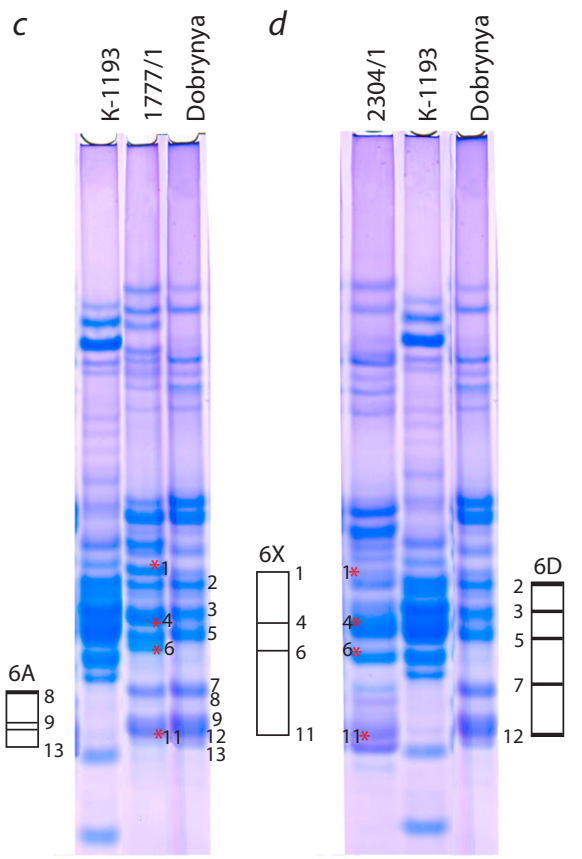

$g$

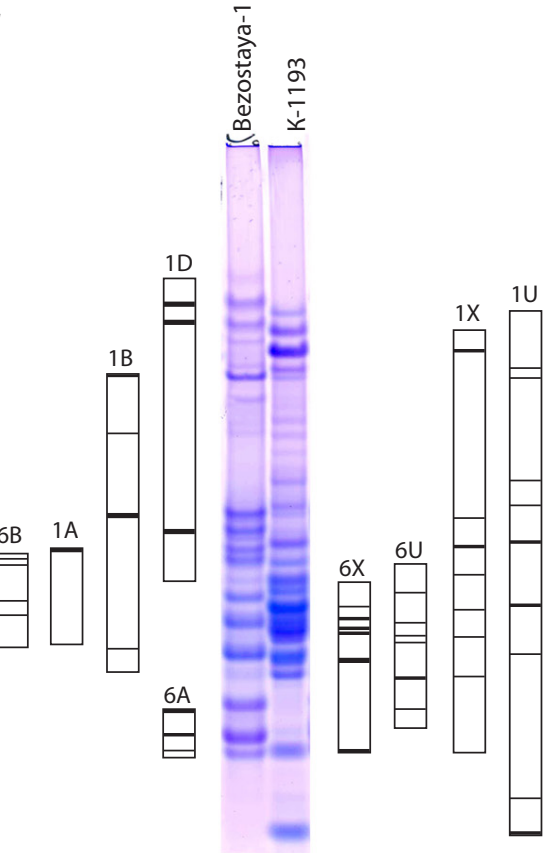

Fig. 2. Gliadin electrophoretic spectra of introgressive lines with chromosome rearrangements of chromosome homoeologous groups 1 and 6 .

K-1193 - the parental line of Ae. columnaris. Blocks of gliadin components controlled by wheat and Aegilops chromosomes are shown in the schemes. Individual components of blocks are shown by numerals. Chromosome substitution lines: $a-6 \mathrm{~A}(6 \mathrm{Uc}) ; b-6 \mathrm{D}(6 \mathrm{Uc})$; $c-6 \mathrm{~A}\left(6 \mathrm{X}^{c}\right) ; d-6 \mathrm{D}(6 \mathrm{Xc}) ; e$ - lines without gliadin components controlled by chromosomes $6 \mathrm{D}, 6 \mathrm{U}$ and $6 \mathrm{X}$. The components controlled by chromosomes $6 \mathrm{~A}$ and $6 \mathrm{~B}$ close in mobility to $6 \mathrm{D}$-controlled components are indicated with arrows; $f-1 \mathrm{D}(1 \mathrm{Xc})$, nulli-6A tetra-6D, absence the components controlled by chromosome 1D are indicated with arrows (left), components controlled by tetra 6D are indicated with arrows (right). The asterisks denote an absence of the gliadin components controlled by chromosome $6 \mathrm{~A} ; g$ - genetic control of Ae. columnaris gliadin, blocks of gliadin components controlled by homoeologous chromosome groups 1 and 6 are schematically represented for Aegilops (right) and wheat (left).

K-1193 parental line kernels were characterized by similar EP spectra.

Lines 1721/1, 1776/1, 1777/4, 2307/1W, 2307/1w, 2308/5, and $1777 / 1$ (see the Table) were developed from the same crossing combination (Dobrynya $\times$ K-1193). Their karyotypes were characterized by monosomic or disomic substitution of wheat chromosome 6A with Aegilops chromosomes $6 \mathrm{U}^{\mathrm{C}}$ or
6X' (Fig. 1, $b, c)$. According to cytological data, chromosomes 4B and 1D were absent in lines1721/1, 1776/1, 1777/4, and $2307 / 1 \mathrm{w}$, where a pair of acrocentric chromosomes appeared instead (Fig. 1, b). C-banding and in situ hybridization with pSc119.2 and pAs1 DNA-probes demonstrated that thise chromosome forms resulted from translocation of the short arm and major part of the long arm of 1D to the 4B long arm 
with a breakpoint at the pericentromeric region of $4 \mathrm{~B}$ and distal section of 1DL (Badaeva et al., 2018).

All the four lines listed had identical gliadin EP spectra coded by the same set of GC locus alleles (see the Table). Gliadin components controlled by chromosome 6A were absent, but polypeptides appear in the spectrum, whose EP mobility corresponded to that of a number of Aegilops components (Fig. 2,b). This confirms the 6A wheat chromosome substitution with Aegilops chromosome and demonstrate the Aegilops gene expression.

All gliadin polypeptides controlled by 1D chromosome were identified in EP spectra for all the four lines, hence the translocated part of chromosome1D included GC locus as well. The GC genes in chromosomes1A, 1B, 6B, and 6D were fully expressed, similarly to the Dobrynya parent wheat cultivar (see Fig. 2, b)

The disomic addition of chromosome $6 \mathrm{U}^{\mathrm{c}}$ was identified in line karyotype $2307 / 1 \mathrm{~W}$, in contrast to the other lines in the group. In this line, the EP spectrum included the components coded by both $6 \mathrm{~A}$ and $6 \mathrm{U}^{\mathrm{c}}$ chromosomes (see Fig. $2, b$ ). Lines with $6 \mathrm{~A}\left(6 \mathrm{U}^{\mathrm{c}}\right)$ substitution and disomic addition of $6 \mathrm{U}^{\mathrm{c}}$ had the same block of EP components, which indicates that the same Aegilops chromosome, i. e. $6 \mathrm{U}^{\mathrm{c}}$, was involved in the introgression.

The block of gliadin components controlled by Gli-Alm allele, which could only be introduced from the Saratovskaya 68 cultivar, was present in the 1777/1 line EP spectrum. Cytogenetic analysis showed that line 1777/1 carried substitution by two Aegilops chromosomes, i. e. $5 \mathrm{X}^{\mathrm{c}}$ and $6 \mathrm{X}^{\mathrm{c}}$ (see Fig. 1, c), uncharacteristic for the rest of the lines from the group (Badaeva et al., 2018). These results indicate random cross-pollination with the Saratovskaya 68 cultivar that occurred when line 1777/1 was synthesized or reproduced. A 6A $\mathrm{a}\left(6 \mathrm{X}^{\mathrm{c}}\right)$ substitution was cytologically identified in the line, which was confirmed by EP analysis (see Fig. 2,c).

The next, i. e. the second, series of lines with numbers 11-16 (see the Table) was obtained involving L-503 common wheat cultivar. The allele composition of GC loci in these lines mostly matched the first parental cultivar biotype, apart from lines 1813 and 2054/3, in which Gli-Bs allele characteristic of the Dobrynya cultivar appeared instead of Gli-B2q, and line 2304/1 with Gli-Alf allele. Karyotypes of lines from this series did not include chromosome $6 \mathrm{D}$, substituted with $6 \mathrm{U}^{\mathrm{c}}$ or in one case with $6 X^{c}$. These substitutions were confirmed by EP analysis of the lines. Disappearance of the components coded by chromosome 6D and appearance of a group of components close in mobility to Aegilops parental line components was observed in lines 1813, 2054/3, 2306/3, and 2310/1 (see Fig. 2, a). The only line, where 6D chromosome was substituted with Aegilops chromosome 6Xc, i. e. 2304/1, possessed a unique composition of gliadin components controlled by Aegilops chromosome. It proves that a chromosome from another Aegilops genome, i. e. $6 \mathrm{X}^{\mathrm{c}}$, was involved in the substitution (see Fig. 2, d).

The next two lines, i. e. 2033/1 and 2034/3-1, were derived from crossings involving Dobrynya and Saratovskaya 68 cultivars. The allele composition of GC loci in these lines was overall consistent with the parental one. Segregating by Gli-A1 locus was observed in line 2034/3-1 (see the Table). The karyotypes of both lines did not include chromosome 6D,

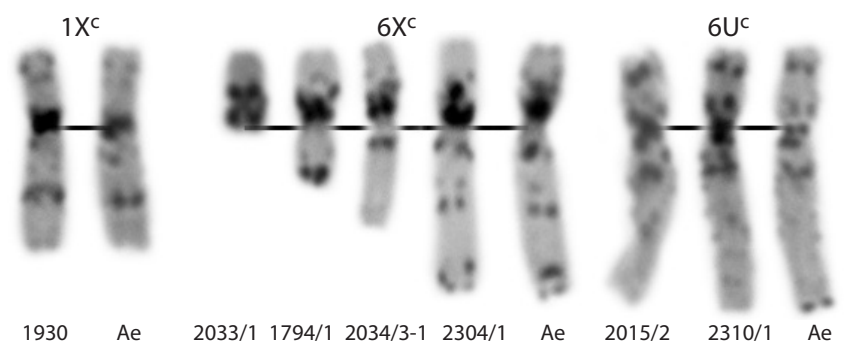

Fig. 3. Comparison of chromosomes $1 X^{c}, 6 U^{c}$ and $6 X^{c}$ detected in introgressive lines with chromosomes of the parental Ae. columnaris accessions K-1193 (Ae).

as they were substituted with the deletion derivatives of chromosome $6 X^{c}$. Thus, chromosome $6 X^{c}$ in 2033/1 line was represented by a short arm telesomic (Fig. 3) and in line 2034/3-1 it had terminal deletion affecting about a half of the long arm. Components controlled by chromosome 6D are present in EP spectra for both lines. Their substitution with components similar to the ones identified in line 2304/1 and coded by Aegilops chromosome $6 \mathrm{X}^{\mathrm{c}}$ was visible only in line 2034/3-1 (see Fig. 2, d). No components coded by chromosome $6 X^{c}$ were identified in the EP spectrum of line 2033/1 (see Fig. 2,e).

Substitution of chromosomes of homoeologous group 1, i. e. $1 \mathrm{D}\left(1 \mathrm{X}^{\mathrm{c}}\right)$, was only identified in line 1930 (Badaeva et al., 2018). It originated from cultivar Л-503 and thus falls into the second group of lines. Cytogenetic analysis showed that chromosomes1D and 6A were absent in the line karyotype (see the Table, Fig. 1, a). It was further confirmed by the EP analysis results: no components controlled by chromosome1D were identified in the gliadin spectrum, while the components close in mobility to Aegilops components were present (see Fig. 2, $f$ ). Polypeptides controlled by wheat chromosomes $1 \mathrm{~A}$ and $1 \mathrm{~B}$ matched the parent cultivar spectrum. Absence of 6A chromosomes was compensated by an additional pair of chromosomes $6 \mathrm{D}$, one of which carried unidentifiable terminal translocation in the long arm that did not affect the GC locus, whose genes were expressed. It was manifested in the form of clear color intensification in components controlled by chromosome 6D (see Fig. 2, $f$ ), which implied a multiple increase in gene dose, and therefore, gene expression in all the four $6 \mathrm{D}$ chromosomes. No components controlled by chromosome $6 \mathrm{~A}$ were visible in the EP image.

Line 1794/1 was not only the derivative of the Dobrynya cultivar but of the Saratovskaya 68 cultivar as well. Consequently, it carried the Gli-Alm allele. The karyotype of line $1794 / 1$ did not include chromosome 6D, as it was substituted with a pair of translocated T7 $\mathrm{U}^{\mathrm{c}} \mathrm{S}: 6 \mathrm{X}^{\mathrm{c} S}$ chromosomes (see Figs. 1, $d, 3)$. The absence of 6D chromosome was further confirmed by EP analysis (see Fig. 2,e). However, no gliadin components controlled by $6 \mathrm{X}^{\mathrm{c}}$ Aegilops chromosome were identified in the EP spectrum.

\section{Discussion}

Before using introgressive lines derived by remote hybridization in breeding practice, they need to be tested for alien genetic material, and this genetic material is to be characterized (Friebe et al., 1996; Molnár-Láng et al., 2014). Cytological approaches (such as differential chromosome banding or in 
situ hybridization) permits identifying substituted/added lines and classifying them. However, these methods are rather labor intensive and not suited for massive analysis. Introduction of molecular genetic markers as a supplement for cytological analysis to characterize introgressive lines enhances the capability for accurate alien material identification, reduces the cost of testing and simplifies the procedure. It also permits evaluating the effect of alien chromosome introgression on gene expression.

EP analysis of gliadin spectra confirmed 6A, 6D, and 1D wheat chromosome substitution with Aegilops homoeologous chromosomes associated with $\mathrm{U}^{c}$ or $\mathrm{X}^{\mathrm{c}}$ genomes in all the lines studied. The substitution manifested in the disappearance of GC gene expression products in chromosomes 6A, 6D or 1D with simultaneous appearance of the gene expression products localized in respective alien chromosomes. Comparison of EP spectra for lines with various wheat gene pools, which carried identical Aegilops chromosomes, showed that neither EP mobility, nor intensity of components within alien chromosome gliadin blocks change, i. e. they do not depend on line genotype. It makes it possible to use these markers to identify individual Ae. columnaris chromosomes in genetic and breeding lines.

The appearance in EP spectra of introgression lines, polypeptides controlled by Aegilops chromosome indicates the gene expression of this chromosome, as well as its functional activity within the alien wheat genome. In turn, alien chromosome does not affect the behavior of fully expressed wheat Gli genes, that is confirmed by the match between hybrids and parental cultivars in terms of gliadin spectrum. Such a "good neighborhood" between wheat and alien genetic material in the same nucleus may be considered as a relative phylogenetic affinity of these two species (or parts of their genetic material), which is determined by reticulate evolution, which is generally typical for the Triticeae tribe.

However, not all substitutions involving Aegilops chromosomes of homoeologous group 6 resulted in appearance of new gliadin components in EP spectra for hybrids. For instance, the analysis of lines with short arm of $6 \mathrm{X}^{\mathrm{c}}$ Aegilops chromosome in the form of translocation (1794/1) or telocentric (2033/1) showed absence of the gliadin components present in lines with full $6 \mathrm{X}^{\mathrm{c}}$ chromosome substitution. GC genes in wheat are known to be localized in terminal short arm sections of chromosomes from homoeologous groups 1 and 6 (Singh, Shepherd, 1988). Nevertheless, GC genes are not expressed in both these lines, in spite of chromosome short arms not being structurally rearranged. On the other hand, all gliadin components controlled by $6 \mathrm{X}^{\mathrm{c}}$ Aegilops chromosome were present in the EP spectrum of 2034/3-1 line with large terminal long arm deletion in this chromosome. Based on these facts, we may infer that genes controlling gliadin synthesis are localized in the proximal part of the $6 \mathrm{X}^{\mathrm{C}}$ Ae. columnaris chromosome long arm. It is possible that GC locus relocation from $6 \mathrm{X}^{\mathrm{c}}$ chromosome short arm to the long one is associated with large species-specific pericentric inversion, accompanying divergence between Ae. columnaris and phylogenetically affine Ae. triaristata. This assumption is supported by cytogenetic analysis results, which identified significant morphological differences in 6 group orthologic chromosomes of X-genome in these species (Badaeva et al., 2004).
Four copies of chromosome 6D (tetra-6D) were identified using cytological methods in line 1930, with terminal long arm translocation identified in one pair. Enhanced intensity of EP components controlled by chromosome 6D indicates that all tetra-6D loci were expressed in line 1930. Independence of gliadin gene expression on the presence of chromosome rearrangements may be observed in the other lines as well. Particularly, all six introgressive lines, in which a major part of the 1D chromosome, including the short arm, was translocated to the 4B chromosome long arm, show fully expressed GC genes in the $1 \mathrm{D}$ chromosome. It shows that the $1 \mathrm{D}$ chromosome functioning does not depend on the loss of a part of its long arm and combination with nonhomologous chromosome from another genome (4BL).

Introgressions of homoeologous group 6 chromosomes were encountered in the sample studied significantly more frequently than those of group 1: $1 \mathrm{D}\left(1 \mathrm{X}^{\mathrm{c}}\right)$ substitution was only identified in one of 18 lines. The absence of substitutions involving chromosome $1 \mathrm{U}^{\mathrm{c}}$ may be due to its low compensatory capability, since the parent K-1193 Ae. columnaris sample had this chromosome rearranged as a result of major translocation. Due to lack of samples carrying substitutions or translocations associated with $1 \mathrm{U}^{\mathrm{c}}$ chromosome, we have only been able to identify gliadin EP component blocks controlled by Aegilops chromosomes 1Xc, 6U , and 6Xc. Spectrum components, whose genetic control remained unidentified, were hypothetically attributed to polypeptides controlled by $1 \mathrm{U}^{\mathrm{c}}$ chromosome (see Fig. 2, g). The data obtained may be used in future research to test breeding material for presence of these chromosomes.

EP spectra analysis of the two species belonging to Aegilops and Triticum genera indicates that there are no individual species-specific EP components. At the same time, we may define specific groups of components inherited as the blocks controlled by linked gene clusters. Component blocks differ in their structure or their pattern. Based on these differences, intraspecific and interspecific diversity can be estimated. The block nature of gliadin component inheritance in Aegilops indicates the similarity between the specimens of these genera in their GC locus organizational structure.

\section{Acknowledgments}

The authors thank S.N. Sibikeev, Head of Genetics and Cytology Laboratory at Agricultural Research Institute for South-East Region, and A.E. Druzhinina for the provided materials. The work was supported in part by the Russian Foundation for Basic Research, project No. 17-04-00087.

\section{Conflict of Interest}

The authors declare they have no conflict of interest.

\section{References}

Badaeva E.D., Amosova A.V., Samatadze T.E., Zoshchuk S.A., Shostak N.G., Chikida N.N., Zelenin A.V., Raupp W.J., Friebe B., Gill B.S. Genome differentiation in Aegilops. 4. Evolution of the U-genome cluster. Plant. Syst. Evol. 2004;246(1-2):45-76.

Badaeva E.D., Badaev N.S., Gill B.S., Filatenko A.A. Intraspecific karyotype divergence in Triticum araraticum (Poaceae). Plant. Syst. Evol. 1994;192:117-145

Badaeva E.D., Ruban A.S., Shishkina A.A., Sibikeev S.N., Druzhin A.E., Surzhikov S.A., Dragovich A.Y. Genetic classification of 
Aegilops columnaris Zhuk. $\left(2 n=4 x=28, \mathrm{U}^{c} \mathrm{U}^{c} \mathrm{X}^{c} \mathrm{X}^{\mathrm{c}}\right)$ chromosomes based on FISH analysis and substitution patterns in common wheat $\times$ Ae. columnaris introgressive lines. Genome. 2018;61(2):131-143. DOI 10.1139/gen-2017-0186.

Damania A.B., Altunji H., Dhaliwal H.S. Evaluation of Aegilops spp. for drought and frost tolerance. Genetic Resources Unit Annual Report, ICARDA. 1992;45-46.

Dvoř́a J. Genome analysis in the Triticum-Aegilops alliance. In: Slinkard A.E. (Ed.) Proc. of the 9th Int. Wheat Genetics Symp., 2-7 Aug. 1998. Saskatoon, Saskatchewan: Printcrafters Inc., 1998; 8-11.

Friebe B., Jiang J., Raupp W.J., McIntosh R.A., Gill B.S. Characterization of wheat-alien translocations conferring resistance to diseases and pests: current status. Euphytica. 1996;91:59-87.

Garg M., Tanaka H., Ishikawa N., Takata K., Yanaka M., Tsujimoto H. A novel pair of HMW glutenin subunits from Aegilops searsii improves quality of hexaploid wheat. Cereal Chem. J. 2008;86:26-32.

Garg M., Tsujimoto H., Gupta R.K., Kumar A., Kaur N., Kumar R., Chunduri V., Sharma N.K., Chawla M., Sharma S., Mundey J.K. Chromosome specific substitution lines of Aegilops geniculata alter parameters of bread making quality of wheat. PLoS One. 2016;11: e0162350.

Gill B.S., Friebe B., Endo T.R. Standard karyotype and nomenclature system for description of chromosome bands and structural aberrations in wheat (Triticum aestivum). Genome. 1991;34:830-839.

Gill B.S., Sharma C., Raupp W.J., Browder L.E., Heachett J.H., Harvey T.L., Moseman J.G., Waines J.G. Evaluation of Aegilops species for resistance to wheat powdery mildew, wheat leaf rust, Hessian fly, and greenbug. Plant Dis. 1985;69:314-316.

Kasarda D.D., Bernardin J.E., Qualset C.O. Relationship of gliadin protein components to chromosomes in hexaploid wheats (Triticum aestivum L.). Proc. Natl. Acad. Sci. USA. 1976;73:3646-3650.

McIntosh R.A., Yamazaki Y., Dubkovsky G., Rogers J., Morris C.F., Appels R., Xia X.C. Catalogue of Gene Symbols for Wheat. The 12th Int. Wheat Genetics Symp., 8-13 Sept. 2013. Yokohama, Japan, 2013;395.

Metakovsky E.V., Novoselskaya A.Yu. Gliadin allele identification in common wheat. 1. Methodological aspects. J. Genet. Breed. 1991; 45:319-323

Molnár-Láng M., Ceoloni C., Doležel J. (Eds.). Alien Introgression in Wheat: Cytogenetics, Molecular Biology, and Genomics. Switzerland: Springer Int. Publ., 2015.

Molnár-Láng M., Molnár I., Szakács É., Linc G., Bedö Z. Production and Molecular Cytogenetic Identification of Wheat-Alien Hybrids and Introgression Lines. In: Tuberosa R., Graner A., Frison E. (Eds.). Genomics of Plant Genetic Resources. Vol. 1. Managing, Sequencing and Mining Genetic Tesources. Springer, 2014;255-284.

Monneveux P., Zaharieva M., Rekika D. The utilisation of Triticum and Aegilops species for the improvement of durum wheat. In: Royo C.,
Nachit M., Di Fonzo N., Araus J.L. (Eds.). Durum Wheat Improvement in the Mediterranean Region: New Challenges. Zaragoza: CIHEAM, 2000;71-81.

Novoselskaya-Dragovich A.Yu. Genetics and genomics of wheat: storage proteins, ecological plasticity, and immunity. Russ. J. Genet. 2015;51(5):476-490. DOI 10.1134/S102279541505004X.

Novoselskaya-Dragovich A.Yu., Krupnov V.A., Saifulin R.A., Puhalskiy V.A. Dynamics of genetic variation at gliadin coding loci in Saratov cultivars of common wheat Triticum aestivum L. for over eight decades of scientific breeding. Russ. J. Genet. 2003;39(10):1130-1137.

Rakszegi M., Molnár I., Lovegrove A., Darkó É., Farkas A., Láng L., Bedo Z., Doležel J., Molnár-Láng M., Shewry P. Addition of Aegilops $\mathrm{U}$ and $\mathrm{M}$ chromosomes affects protein and dietary fiber content of wholemeal wheat flour. Front. Plant Sci. 2017;8:1529. DOI $10.3389 /$ fpls.2017.01529.

Rawat N., Neelam K., Tiwari V.K., Randhawa G.S., Friebe B., Gill B.S., Dhaliwal H.S. Development and molecular characterization of wheat-Aegilops kotschyi addition and substitution lines with high grain protein, iron, and zinc. Genome. 2011;54:943-953.

Schneider A., Molnár I., Molnár-Láng M. Utilisation of Aegilops (goatgrass) species to widen the genetic diversity of cultivated wheat. Euphytica. 2008;163:1-19.

Shepherd K.W. Chromosomal control of endosperm proteins in wheat and rye. In: Finlay K.W., Sherherd K.W. (Eds.). Proc. of the 3rd Int. Wheat Genetics Symp. Canberra: Austral. Acad. Sci., 1968;86-96.

Shishkina A.A., Dragovich A.Yu., Rouban A.S., Sibikeev S.N., Druzhin A.E., Badaeva E.D. Development of the genetic classification of Aegilops columnaris Zhuk. chromosomes based on the analysis of introgression lines Triticum aestivum $\times$ Ae. columnaris. Vavilovskii Zhurnal Genetiki i Selektsii $=$ Vavilov Journal of Genetics and Breeding. 2017;21(2):241-249. DOI 10.18699/VJ17.243 (in Russian)

Singh N.K., Shepherd K.W. Linkage mapping of genes controlling endosperm storage proteins in wheat: 1 . Genes on the short arms of group 1 chromosomes. Theor. Appl. Genet. 1988;75:628-641.

Tiwari V., Rawat N., Neelam K., Kumar S., Randhawa G., Dhaliwal H. Substitutions of $2 \mathrm{~S}$ and $7 \mathrm{U}$ chromosomes of Aegilops kotschyi in wheat enhance grain iron and zinc concentration. Theor. Appl. Genet. 2010;121(2):259-269.

Upelniek V.P., Novoselskaya-Dragovich A.Yu., Shishkina A.A., Mel'nik V.A., Dedova L.V., Kudrjavtsev A.M. The laboratory analysis of wheat seed proteins. Technological instruction. Diagnostics of varietal identity and purity of seed wheat. Moscow: Vavilov Institute of General Genetics Publ., 2013. (in Russian)

Warham E.J., Mujeeb-Kazi A., Rosas V. Karnal bunt (Tilletia indica) resistance screening of Aegilops species and their practical utilization for Triticum aestivum improvement. Can. J. Plant Pathol. 1986; 8:65-70. 